\title{
RELATIONS BETWEEN BIG FIVE PERSONALITY TRAITS MODEL AND ACHIEVEMENT MOTIVE IN ATHLETES
}

\section{RELACIÓN DE LA DIMENSIÓN DE PERSONALIDAD DEL MODELO DE LOS CINCO GRANDES Y LA MOTIVACIÓN DE LOGRO EN LOS DEPORTISTAS}

\author{
Biljana Mirković, Sanja Radetic Lovric \\ Faculty of Philosophy, University of Banja Luka, Bosnia and Herzegovina
}

\begin{abstract}
The achievement motive is a relevant factor for sports success. Many athletes do not achieve success proportional to their potential possibilities precisely because they do not have sufficiently high achievement motive. The aim of this study was to examine the relationship between the Big Five personality traits model and achievement motive in athletes. The survey encompassed 301 athletes from the Republic of Srpska. We applied the Big Five Inventory and Achievement Motive Scale. A series of hierarchical regression analysis was used to examine the predictive contribution of personality traits to achievement motive and its components, after removing the impact of demographic variables on achievement motive. The obtained results indicate a significant predictive power of personality traits for achievement motive. The most powerful predictor of the total score of achievement motive was conscientiousness. By observing the components of the achievement motive, conscientiousness proved to be a significant positive predictor of all components of achievement motive. Other personality traits of the Big Five model have proved to be significant predictors of one or more components of achievement motive. The obtained results are important for researchers, in order to better understand achievement motive in sport, but also for sports coaches and selectors deciding on the athletes for competitions.
\end{abstract}

Key words: ACHIEVEMENT / PERSONALITY TRAITS / ACHIEVEMENT MOTIVE

\begin{abstract}
EXTRACTO
La motivación de logro es un factor relevante para el éxito en el deporte. Muchos deportistas no logran éxito proporcional a sus posibilidades potenciales precisamente por no tener expresada de manera suficiente la motivación de logro. El objetivo de la presente investigación ha sido examinar la relación entre la dimensión de personalidad del modelo de los cinco grandes y la motivación de logro en los deportistas. La investigación se ha realizado en la muestra de 301 deportistas de la República Serbia. Se ha aplicado el Inventario de los cinco grandes y la Escala de motivaciones de logro. Por una serie de análisis regresivos jerárquicos se ha examinado la contribución predictiva de la dimensión de personalidad a la motivación de logro y a sus componentes, después de eliminar la influencia de variables demográficas en la motivación de logro. Como el más fuerte predictor de la suma total de motivaciones de logro se mostró la conciencia. Observando los componentes de la motivación de logro, la conciencia se mostró como importante predictor positivo de todos los componentes de la motivación de logro. Las demás dimensiones de personalidad del modelo de los cinco grandes se mostraron como predictores importantes de uno o de varios componentes de la motivación de logro. Los resultados obtenidos son importantes tanto para los examinadores, para comprender mejor las motivaciones de logro en el contexto de deporte, como también para los entrenadores deportivos al hacer la selección de deportistas para las competencias.
\end{abstract}

Palabras claves: LOGRO / RASGOS DE PERSONALIDAD / MOTIVACIÓN DE LOGRO 


\section{INTRODUCTION}

Since competition and effect evaluation are some of the basic components in sport, the achievement motive is an important factor of sport success. The achievement motive has a direct impact on the effects of sports activities presented through the sport result (Singer, 1972). In fact, results of different studies indicate that athletes with prominent the achievement motive expresses strong energy aimed at achieving the goal, perceive their competence as high and feel that they control achievement. They are willing to take a risk which is motivating for them, they are realistic and do not seek to achieve the impossible; they see a success as something stable and depending on the internal factors which are under the control, they are concentrated on their tasks and are not pleased with reaching easily achieved goals but the success that requires the ultimate efforts, and achieving such success increases their level of aspiration (Vujanović, 2015). Also, it is a fact that many athletes do not achieve a success proportional to their potential precisely due to the lack of sufficiently prominent the achievement motive (Pajević, 2006).

The achievement motive in literature is defined as a relatively permanent disposition whose essence is composed of more or less expressed need for competence, i.e. being successful in situations when it is necessary to reach or exceed a certain standard of success (Rheinberg, 2004). According to McClelland (McClelland, Atkinson, Clark, \& Lowell, 1953), the author who pointed to the importance of the achievement motive, this complex motivational disposition contains two components: personal tendency to set up a goal and competition with others.

The modern studies of the achievement motive structure conducted by Franceško, Mihić, and Bala (2002a) indicate that there are four components of this complex motivational disposition: competition with other people, persistence in achieving a goal, goal achievement as a source of satisfaction and orientation towards planning. The conclusion of these authors is that the two basic components included by the achievement motive are making efforts to achieve what is considered valuable - setting up goals, and how to make yourself prominent - competition with others (Franceško et al., 2002a), which is corresponding to McClelland's concept of the achieve- ment motive. The other two separated components are instrumental traits or behavior forms developed by a person in order to be successful when competing with others and/or achieving goals. Namely, persons prone to competing and/or achieving goals, but lack the persistence, endurance, and orientation towards planning, will not probably be successful (Francesko et al., 2002a). Recent studies (Arsenijević-Puhalo \& Puhalo, 2006; Franceško, Kodžopeljić \& Mihić, 2002b; Mihić, Sakotić-Kurbalija \& Franceško, 2005) have confirmed such structure of the achievement motive. Finally, by its very nature, the achievement motive is classified in the category of social motive (McClelland et al., 1953), which means that to a large extent it is the result of the socialization process. Results of numerous studies (Beck, 2000; Franceško et al., 2002b; Lazarević, 2011; Schunk, 2004) have shown that social factors, such as culture, social values, family, school, etc. influence the level of achievement motive development.

The Five-Factor Model of Personality (McCrae \& Costa, 1990) assumes that the space of the basic personality structure can be described along five broad dimensions: Extraversion, Conscientiousness, Agreeableness, Openness to Experience and Neuroticism. Extraversion refers to the degree to which an individual actively engages their social environment. Activeness, sociability, and adventurousness are all traits associated with extraversion (McCrae \& Costa, 1990). Conscientiousness refers to the degree to which an individual follows social norms and engages in goaldirected behavior. Responsibility, deliberateness, and organization are all traits associated with conscientiousness (McCrae \& Costa, 1990). Agreeableness refers to the degree to which an individual exhibits a cooperative and confidence toward others. Kindness, cooperative, and unselfish are all traits associated with agreeableness (McCrae \& Costa, 1990). Openness to experience refers to the degree to which an individual accepts new or unconventional thoughts and experiences. Imaginativeness, curiousness, and foresightedness are all traits associated with openness to experience (McCrae \& Costa, 1990). Neuroticism refers to the emotional stability and adjustment of an individual. Traits associated with neuroticism include emotional, temperamental, and anxious (McCrae \& Costa, 1990). The Five-Factor Model of Personality is a comprehensive taxonomy of the personality trait which, with five factors, encompasses the normal and 
pathologically unique field of personality (McCrae \& Costa, 1990).

The great attention in sport is paid to the selection of talented athletes for a particular type of sport. A criterion of different programs for 'talent scouting' is mostly based on correlations between the innate abilities and requirements of a certain sport, based on which they try to predict the potential maximum range of sports success and achievement (DurandBush \& Salmela, 2001; Lidor, Côté, \& Hackfort, 2009). However, athletes nowadays face great challenges and temptations during their sports careers, and the realization of their talents and efforts is, to a large extent, determined by their personality and motivation to achieve sports results (Cox, 2005; Egloff \& Gruhn, 1996; Elumaro, 2016; Horga, 2009). Despite this, there were no papers dealing with the relations between the personality traits and the achievement motive in athletes while searching through the available literature. There are only a few studies about the relations between personality traits of the Big Five model and the achievement motive in an academic and corporate environment. The results of these studies (Busato, Prins, Elshout \& Hamaker, 2000; Dweck \& Leggett, 1988; Hart, Stasson, Mahoney \& Story, 2007; Kaiser \& Ozer, 1994; Komarraju, Karau \& Schmeck, 2009; Sharma, 2013) show that an individual's achievement motive in the academic and working context, is to a considerable extent determined by personality traits of the Big Five model. Therefore, the aim of this study was to examine the relations between personality traits of the Big Five model and the achievement motive in athletes. Based on the results of the existing studies (Busato et al., 2000; Costa \& McCrae, 1988; Dveck \& Leggett, 1988; Hart et al., 2007; Kaiser \& Ozer, 1994), it can be assumed that personality traits of the Big Five model also significantly determine the achievement motive in athletes.

\section{METHOD}

\section{Respondents}

The research involved 301 athletes. The sample consisted of $68,2 \%$ male and $31,2 \%$ female, aged 18 to $33(M=21.34, S D=2.83)$. The average length of the sports service is 9 years $(M=9.20, S D=4.31)$. More than half of the respondents, $60.8 \%$ of them are professionally engaged in sports, and $39.2 \%$ are recreational sports practitioners. Most of respondents (31.5\% of them) are engaged in football, then basketball (22.7\%), karate (12.5\%), handball (8.6\%), fitness $(6.5 \%)$, dance $(5,3 \%)$, volleyball (4.9\%), tennis (4.2\%) and bodybuilding (3.8\%). Respondents are members of various sports clubs from the Republic of Srpska.

The survey was conducted in September and October 2019. The data were collected during visiting clubs of respondents. The participation was voluntary and anonymous. Prior to the start of the examination, the respondents were explained that the collected data would be used solely for research purposes, and then they were handed questionnaires which they completed in about 20 minutes.

\section{Instruments}

Achievement Motive Scale (MOP2002; Franceško et al., 2002b) consists of 55 items distributed in four subscales examining components of the achievement motive: Competition with others, Persistence in goal achieving, Goal achievement as a source of satisfaction and Orientation towards planning. The respondents had to evaluate to what extent they agree with each item (from 1 - completely disagree to 5 - completely agree) using a five-point Likert-type scale. The reliability of the subscales measured by Cronbach's alpha, for this study, was 90 for Competition with others, .77 for Persistence in goal achieving, .86 for Goal achievement as a source of satisfaction, .82 for Orientation towards planning, and .92 for the whole scale.

Big Five Inventory (BFI; John, Donahue \& Kentle, 1991). The questionnaire contains 44 items distributed in five sub-scales that measure personality traits: Extraversion, Openness to experience, Conscientiousness, Agreeableness, and Neuroticism. The items are formulated as short phrases based on the adjectives of traits that are the prototypes of the Big Five model. The task of respondents was to evaluate to what extent they agree with each item (from 1 - completely disagree to 5 - completely agree) using a fivepoint Likert-type scale. The reliability of the subscales measured by Cronbach's alpha, for this study, was .76 for Extraversion, .70 for Openness to experience, .85 for Conscientiousness, .69 for Agreeableness and .72 for Neuroticism.

Demographic Characteristics Questionnaire which was designed for this research, consisted of three 
questions about the following demographic characteristics: gender, age and length of the sports service.

\section{Data analysis}

In addition to the basic indicators of descriptive statistics and correlation analysis, a series of hierarchical regression analyses (for excluding the potential influence of demographic variables on the achievement motive) was applied to examine the predictive contribution of personality traits for the achievement motive and its components. The analysis was done in SPSS 20.0 software package.

\section{RESULTS}

Table 1. presents the descriptive statistical measures and correlations between variables used in the study.

Table 1. Descriptive statistics and correlations between the examined variables

\begin{tabular}{|c|c|c|c|c|c|c|c|c|c|}
\hline & \multirow{2}{*}{$\mathbf{M}$} & \multirow{2}{*}{ SD } & \multirow{2}{*}{ Sk } & \multirow{2}{*}{$\mathbf{K u}$} & \multicolumn{5}{|c|}{ Correlations } \\
\hline & & & & & COP & PAG & AGS & OTP & TAM \\
\hline COP & 68.10 & 12.92 & -.35 & -.16 & 1.00 & & & & \\
\hline PAG & 60.84 & 9.35 & .82 & .68 & $.36^{* *}$ & 1.00 & & & \\
\hline AGS & 56.06 & 6.344 & -.57 & -.08 & $.49^{* *}$ & $.67^{* *}$ & 1.00 & & \\
\hline OTP & 26.79 & 6.19 & -.18 & -.42 & $.38^{* *}$ & $.54^{* *}$ & $.58^{* *}$ & 1.00 & \\
\hline TAM & 211.79 & 27.52 & -.25 & .29 & $.80^{* *}$ & $.79^{* *}$ & $.82^{* *}$ & $.73^{* *}$ & 1.00 \\
\hline $\mathbf{E}$ & 30.95 & 5.00 & -.62 & .73 & $.14^{*}$ & $.32^{* *}$ & $.26^{* *}$ & .08 & $.26^{* *}$ \\
\hline $\mathbf{A}$ & 31.89 & 4.80 & -.33 & .30 & -.04 & .04 & .09 & .05 & .02 \\
\hline $\mathrm{C}$ & 34.89 & 5.99 & -.51 & .06 & $.27^{* *}$ & $.72^{* *}$ & $.55^{* *}$ & $.53^{* *}$ & $.63^{* *}$ \\
\hline $\mathbf{N}$ & 20.54 & 4.87 & -.03 & -.42 & .03 & $-.24^{* *}$ & $-.15^{*}$ & -.08 & $-.12^{*}$ \\
\hline O & 31.25 & 5.09 & -.04 & -.29 & .10 & $.40^{* *}$ & $.36^{* *}$ & $.21^{* *}$ & $.31^{* *}$ \\
\hline
\end{tabular}

Legend. $\mathrm{COP}=$ Competition with other people; $\mathrm{PAG}=$ Persistence in achieving a goal; AGS $=$ Goal achievement as a source of satisfaction; OTP = Orientation towards planning; $\mathrm{TAM}=$ Total score at the achievement motive scale; $\mathrm{E}=$ Extraversion; A = Agreeableness; $\mathrm{C}=$ Conscientiousness; $\mathrm{N}=$ Neuroticism; $\mathrm{O}=$ Openness to experience

$* p<.05 ; * * p<.01$.

Measures of average and variability, skewness and kurtosis for the Achievement Motive Scale and the Big Five Inventory (Table 1) do not indicate major distribution deviations compared to a normal distribution (Tabachnick \& Fidell, 2001).

Analysis of correlations between the components of the achievement motive (Tabela 1) shows that all relations are significant and positive $(.38<r$ $<.67)$. Considering the correlations between the personality traits of the Big Five model and the achievement motive, we can see that extraversion, conscientiousness, and openness to experience are in significant positive, while neuroticism is insignificant negative correlation with the achievement motive and its components (only a component of the achievement motive: competition with others, is not in a significant correlation with openness to experience and neuroticism). The achievement motive and its four components are in the highest correlation with conscientiousness $(.27<r<.72)$.

Table 2 shows the results of a series of hierarchical regression analyses conducted with the aim to examine the predictive contribution of personality traits to the achievement motive and its components, beyond and above the variance explained by demographic variables. In each hierarchical regression analysis, the first step was to enter a set of demographic variables; gender (binary variable coded as $0=$ male, $1=$ female), age and length of the sports service, and then to enter personality traits in the second phase. 
Table 2. The predictive contribution of personality traits of the Big Five model to the achievement motive

\begin{tabular}{|c|c|c|c|c|c|c|c|c|c|c|}
\hline \multirow[t]{3}{*}{ Criterion } & \multicolumn{2}{|c|}{$\mathrm{COP}$} & \multicolumn{2}{|c|}{ PAG } & \multicolumn{2}{|c|}{ AGS } & \multicolumn{2}{|c|}{ OTP } & \multicolumn{2}{|c|}{ TAM } \\
\hline & \multicolumn{2}{|c|}{ Model } & \multicolumn{2}{|c|}{ Model } & \multicolumn{2}{|c|}{ Model } & \multicolumn{2}{|c|}{ Model } & \multicolumn{2}{|c|}{ Model } \\
\hline & 1 & 2 & 1 & 2 & 1 & 2 & 1 & 2 & 1 & 2 \\
\hline Predictor & $\beta$ & $\beta$ & $\beta$ & $\beta$ & $\beta$ & $\beta$ & $\beta$ & $\beta$ & $\beta$ & $\beta$ \\
\hline Gender & $-.19^{* *}$ & $-.20^{\star \star}$ & -.07 & -.07 & -.04 & -.05 & -.08 & -.06 & $-.14^{*}$ & $-.14^{* *}$ \\
\hline Age & $-.16^{*}$ & $-.18^{\star *}$ & .00 & -.06 & -.10 & $-.14^{*}$ & .03 & -.02 & -.09 & $-.14^{* *}$ \\
\hline LSS & $.22^{* *}$ & $.17^{\star *}$ & .13 & .02 & $.17^{\star \star}$ & .09 & -.00 & -.07 & $.18^{\star \star}$ & .09 \\
\hline E & & .10 & & $.10^{*}$ & & .07 & & -.07 & & $.10^{*}$ \\
\hline A & & -.09 & & $-.12^{* *}$ & & -.02 & & -.02 & & $-.09^{*}$ \\
\hline $\mathrm{C}$ & & $.29^{\star *}$ & & $.67^{\star *}$ & & $.50^{\star *}$ & & $.58^{\star \star}$ & & $.62^{\star \star}$ \\
\hline $\mathbf{N}$ & & $.15^{*}$ & & .01 & & .07 & & .09 & & $.12^{*}$ \\
\hline O & & .01 & & $.15^{\star *}$ & & $.19^{\star \star}$ & & .07 & & $.11^{\star}$ \\
\hline $\mathbf{R}^{2}$ & .07 & .15 & .01 & .56 & .01 & .35 & .00 & .29 & .04 & .45 \\
\hline F & $8.325^{\star *}$ & $7.733^{* *}$ & 2.116 & $48.111^{\star *}$ & 2.603 & $20.764^{* *}$ & .644 & $16.345^{\star *}$ & $4.761^{\star *}$ & $30.963^{* *}$ \\
\hline$\Delta \mathrm{R}^{2}$ & & .10 & & .55 & & .34 & & .29 & & .41 \\
\hline$\Delta \mathrm{F}$ & & $6.877^{\star *}$ & & $74.118^{\star *}$ & & $30.862^{\star *}$ & & $25.604^{\star *}$ & & $44.532^{\star *}$ \\
\hline
\end{tabular}

Legend $. \mathrm{COP}=$ Competition with other people; $\mathrm{PAG}=$ Persistence in achieving a goal; $\mathrm{AGS}=$ Goal achievement as a source of satisfaction; $\mathrm{OTP}=$ Orientation towards planning; TAM $=$ Total score at the achievement motive scale; $\mathrm{E}=$ Extraversion; $\mathrm{A}=\mathrm{Agreeableness}$; $\mathrm{C}=$ Conscientiousness; $\mathrm{N}=$ Neuroticism; $\mathrm{O}=$ Openness to experience; $\mathrm{LSS}=$ Length of the sports service

$* p<.05$. ** $p<.01$.

The obtained results (Table 2) show that all models with included predictor set of personality traits are statistically significant. Also, results show that for each component of the achievement motive, personality traits introduce statistically significant changes in the percentage of the explained variance compared to the model whose predictor set includes only demographic variables. This contribution ranges from $11 \%$ (in case of component: competition with others) up to $56 \%$ of the explained variance (for the component: persistence in goal achieving). The trend of growth in the percentage of the explained variance after introducing a set of personality traits indicates the significant predictive power of Big Five personality traits for achievement motive.

By observing the components of achievement motive, it can be seen that conscientiousness is a significant positive predictor of all components of achievement motive. The extraversion is a significant positive predictor of component: persistence in achieving a goal $(\beta=.10, p<.05)$, and the agreeableness is a significant negative predictor of component: competition with other people $(\beta=.15$, $p<.05)$. The neuroticism is a significant positive predictor of component: competing with others $(\beta=.15, p<.05)$, while openness to experience presents a significant positive predictor of component: goal achievement as a source of satisfaction $(\beta=.19, p$ $<.01)$ and component: persistence in achieving a goal $(\beta=.15, p<.01)$.

By observing the total score of achievement motive, it can be seen that all personality traits of Big Five model are significant positive predictors of the total score of achievement motive, except the agreeableness which is a significant negative predictor. Consciousness is the most powerful predictor of the total score of achievement motive $(\beta=.62, p<.01)$. 


\section{DISCUSSION}

Based on the results of the existing studies, which established a significant relationship between personality traits of the Big Five model and achievement motive in an academic and corporate environment, the aim of this study was to examine the relations between personality traits of the Big Five model and achievement motive in athletes. The obtained results show that the personality traits of the Big Five model significantly determine the achievement motive in athletes.

Conscientiousness proved to be the most powerful, positive, predictor of the total score of the achievement motive. By observing the components of achievement motive, conscientiousness proved to be a significant positive predictor of all components of achievement motive. Conscientiousness represents the ability of self-control in a sense of a self-disciplined tendency towards goals and strict adherence to one's own principles (McCrae \& Costa, 1990). Since conscientiousness is a trait characterized by persistence (McCrae \& Costa, 1990), we can say that its connection to all components of achievement motive is an expected result. The obtained result is in accordance with the results of previous studies which show that the conscientiousness is in the most powerful correlation with the achievement motive in academic and corporate environment (Busato et al., 2000; Dweck \& Leggett, 1988; Hart et al., 2007; Kaiser \& Ozer, 1994; Komarraju et al., 2009; Sharma, 2013).

Openness to experience proved to be a significant positive predictor of the total scores of achievement motive, and its components: persistence in goal achieving and goal achievement as a source of satisfaction. These results show that open-minded people, who are dedicated to finding information and have an active approach to enriching their quality of life (McCrae \& Costa, 1990), also tend to be persistent in achieving goals and to perceive the achieved goals as a reward. In addition, the study conducted by Hart et al. (2007) indicated a positive relationship between openness and achievement motive in an academic context, and the study performed by Dweck \& Leggett (1988) pointed to a positive relationship between openness and achievement motive in the work environment.
Agreeableness proved to be a significant negative predictor of the total score of achievement motive, and its component: persistence in goal achieving. These results show that open-minded people, who are dedicated to finding information and have an active approach to enriching their quality of life (McCrae \& Costa, 1990), also tend to be persistent in achieving goals and to perceive the achieved goals as a reward. In addition, the study conducted by Hart et al. (2007) indicated a positive relationship between openness and achievement motive in an academic context, and the study performed by Dweck \& Leggett (1988) pointed to a positive relationship between openness and achievement motive in the work environment.

Extraversion proved to be a significant positive predictor of the total score of achievement motive, and its component: persistence in goal achieving. Extraversion implies vitality and energy which can be invested into life goals (Roberts, O'Donnell \& Robins, 2004). Also, extraversion is a trait characterized by activity, enthusiasm, energy, and firmness (McCrae \& Costa, 1990), and therefore it is not surprising that with athletes it results in persistence in goal achieving. Also, the studies conducted by Komarraju et al. (2009) and Sharma (2013) pointed out a positive relation between extraversion and achievement motive in a corporate environment, while the study of Busato et al. (2000) emphasized positive relation between extraversion and achievement motive in an academic environment.

Contrary to the findings of the previous studies that indicate negative relation between neuroticism and achievement motive in academic (Hart et al., 2007) and corporate environment (Komarraju et al., 2009; Sharma, 2013), neuroticism proved to be a significant positive predictor of the total score of achievement motive in athletes. Also, neuroticism represents a significant positive predictor of achievement motive component: competition with others, which implies that concern and anxiety in sport context contribute to the tendency of an individual to be prominent and more successful than others.

Finally, although the achievement motive belongs to the category of social motive (McClelland et al., 1953), the results of this study show that personality traits of the Big Five model significantly determine achievement motive in athletes. 


\section{CONCLUSION}

The results of this study show that the personality traits of the Big Five model significantly determine the achievement motive in athletes, and the most powerful determinant is conscientiousness. The obtained results are important for researchers, in order to better understand the achievement motive in the context of sport, but also for sports coaches and

\section{REFERENCES}

1. Arsenijević-Puhalo, A. and Puhalo, S. (2006). Motiv postignuća menadžerki i menadžera u Banjoj Luci i Sarajevu [ A motive for the achievements of managers and managers in Banja Luka and Sarajevo, In Serbian]. In B. Kuzmaović and Z. Krnjaić (eds.), Zbornik radova Empirijska istraživanja u psihologiji 2006. (str. 227-234). Beograd: Institut za psihologiju.

2. Beck, R. C. (2000). Motivacija - Teorije i načela.[Motivation - Theories and Principles, In Croatian] Jastrebarsko: Naklada Slap.

3. Busato, V. V., Prins, F. J., Elshout, J. J., \& Hamaker, C. (2000). Intellectual ability, learning style, personality, achievement motivation and academic success of psychology students in higher education. Personality and Individual Differences, 29(6), 1057-1068. Doi; 10.1016/ S0191-8869(99)00253-6

4. Cox, R. H. (2005). Psihologija sporta - Koncepti i primjene. Jastrebarsko: Naklada Slap.

5. Durand-Bush, N. \& Salmela, J. H. (2001). The development of talent in sport. In: R. N. Singer, H. A. Hausenblas, \& C. M. Janelle (Eds.), Handbook of sport psychology $2^{\text {nd }}$ ed. (pp. 269-289). New York: Wiley.

6. Dweck, C. S. \& Leggett, E. L. (1988). A Social-Cognitive Approach to Motivation and Personality. Psychological Review, 95(2), 256-273. Doi: 10.1037/0033295X.95.2.256

7. Egloff, B. \& Gruhn, A. J. (1996). Personality and endurance sport. Personality and individual differences, 21(2), 223-229. Doi: 10.1016/0191-8869(96)00048-7.

8. Elumaro, A. I. (2016). Personality, grit and sporting achievement. Journal of sports and physical education, 3(1), 14-17. Doi: 10.9790/6737-0311417

9. Franceško, M., Mihić, V., and Bala, G. (2002). Struktura motiva postignuća merena skalom MOP2002. [Structure of the achievement motives measured by selectors when selecting candidates for competitions. Namely, knowledge of personality traits can make it easier to assess the athlete's achievement motive, and in that way help in the selection of candidates for the competition. Since the achievement motive is a relevant factor for success in sport, it would be useful if further studies could examine the influence of other personal characteristics on the achievement motive in athletes.

the MOP2002 scale, In Serbian] In B. Čukić and M. Franceško (eds.), Ličnost u više kulturnom društvu - Zbornik odseka za psihologiju Filozofskog fakulteta u Novom Sadu, 4 (pp 134-143). Novi Sad: Filozofski fakultet

10. Franceško, M., Kodžopeljić, J., and Mihić, V. (2002). Neki socio-demografski i psihološki korelati motiva postignuća.[Some socio-demographic and psychologically correlate motives of achievemen. In Serbian] Psihologija, 35 (1-2): 65-79.

11. Hart, J. W., Stasson, M. F., Mahoney, J. M., \& Story, P. (2007). The Big Five and Achievement Motivation: Exploring the Relationship between Personality and a Two Factor Model of Motivation. Individual Differences Research, 5 (4), 267-274.

12. Horga, S. (2009). Psihologija sporta. [Psychology of sport. In Croatian]. Zagreb: Kineziološki fakultet.

13. John, O. P., Donahue, E. M., \& Kentle, R. L. (1991). The "Big Five" Inventory-Versions $4 a$ and 54. Berkeley: University of California, Berkeley, Institute of Personality and Social Research.

14. Kaiser, R. T. \& Ozer, D. J. (1997). Emotional stability and goal-related stress. Personality and Individual Differences, 22(3), 371-379. Doi: 10.1016/S01918869(96)00208-5

15. Komarraju, M., Karau, S. J., \& Schmeck, R. R. (2009). Role of the Big Five Personality Traits in Predicting College Students' Academic Motivation and Achievement. Learning and Individual Differences, 19(1), 4752. Doi:10.1016/j.lindif.2008.07.001

16. Lazarević, LJ. (2011). Psihološke osnove fizičke kulture. [Psychological basis of physical culture, In Serbian]. Beograd: Visoka sportska i zdravstvena škola.

17. Lidor, R., Côté, J. \& Hackfort, D. (2009). ISSP position stand: To test or not to test? The use of physical skill tests in talent detection and in early phases of sport development. International Journal of Sport and Ex- 
ercise Psychology, 7(2), 131-146. Doi:10.1080/161219 7X.2009.9671896

18. McClelland, D. C. Atkinson, J. W., Clark, R. A., \& Lowell, E. L. (1953). The Achievement motive. New York: Appleton-Century-Crofts.

19. McCrae. R. R. \& Costa, P. T. Jr. (1990). Personality' in adulthood. New York: Guilford.

20. Mihić, V., Šakotić-Kurbalija, J., and M. Franceško (2005): Motiv postignuća. Lokus kontrole kao motivacioni faktori evropskog identiteta. Psihologija, 38( 4), 445-459.

21. Pajević, D. (2003). Psihologija sporta i rekreacije. [Psychology of sport and recreation. In Bosnian]Laktaši: Grafomark.

22. Rheinberg. F. (2004). Motivacija.[ Motivation. In Croatian] Jastrebarsko: Naklada Slap.
23. Roberts, B. W., O’Donnell, M., \& Robins, R. W. (2004). Goal and personality trait development in emerging adulthood. Journal of Personality and Social Psychology, 87(4), 541-555. Doi: 10.1037/0022-3514.87.4.541

24. Schunk, D. H. (2004). Learning theories-An educational perspective. New Jersey, Pearson Prentice Hall.

25. Sharma, E. (2013). Personality Mapping: Tool to Analyze Achievement Orientation. iBusiness, 5, 59-64. Doi: 10.4236/ib.2013.52007

26. Singer, R. N. (1972). Coaching, Athletics and Psychology. New York: McGraw Hill Book.

27. Tabachnick, B. G. \& Fidell, L. S. (2001). Using Multivariate Statistics - 4th Edition. Boston: Allyn and Bacon.

28. Vujanović, S. (2015). Motivacija i sport. [Motivation and sport. In Serbian]. Aktuelno u praksi, 25(1), 16 24.

Submitted: 07.02.2019.

Accepted: 09.03. 2019.

Published Online First: 11.07.2019. 


\title{
РЕЛАЦИЈЕ ДИМЕНЗИЈА ЛИЧНОСТИ МОДЕЛА ВЕЛИКИХ ПЕТ И МОТИВА ПОСТИГНУТА КОД СПОРТИСТА
}

\author{
Биљана Мирковић, Сања Радетић Ловрић \\ Филозофски факултет, Универзитет у Бања Луци, Босна и Херцеговина
}

\begin{abstract}
Сажетак
Мотив постигнућа је релевантан фактор за успјех у спорту. Многи спортисти не постигну успјех пропорционалан својим потенцијалним могућностима управо зато што немају довољно изражен мотив постигнућа. Циљ овог истраживања је био испитати релације димензија личности модела Великих пет и мотива постигнућа код спортиста. Истраживање је спроведено на узорку од 301 спортисте из Републике Српске. Примењен је Инвентар Великих пет и Скала мотива постигнућа. Серијом хијерархијских регресионих анализа испитан је предиктивни допринос димензија личности мотиву постигнућа и његовим компонентама, након уклањања утицаја демографских варијабли на мотив постигнућа. Најснажнијим предиктором укупног скора мотива постигнућа показала се савјесност. Посматрајући компоненте мотива постигнућа, савјесност се показала значајним позитивним предиктором свих компоненти мотива постигнућа. Остале димензије личности модела Великих пет показале су значајним предикторима једне или више компоненти мотива постигнућа. Добијени налази су значајни како за истраживаче, ради бољег разумјевања мотива постигнућа у контексту спорта, тако и за спортске тренере приликом селекције спортиста за такмичења.
\end{abstract}

Кључне ријечи: ПОСТИГУЋЕ / ЦРТЕ ЛИЧНОСТИ / МОТИВ ПОСТИГНУЋА

\section{УВОД}

Будући да је у спорту једна од основних компоненти такмичење и вредновање учинка, мотив постигнућаје важан факторспортскеуспјешности. Мотив постигнућа директно утиче на ефекте спортске активности које су оличене у спортском резултату (Singer, 1972). Наиме, резултати различитих истраживања показују да спортисти са наглашеним мотивом постигнућа изражавају снажну енергију усмјерену на постизање циља, опажају своју компетентност као високу и осјећају да је постигнуће под њиховом контролом, спремни су на ризик који на њих дјелује мотивишуће, реални су и не покушавају да постигну немогуће, успјех доживљавају као нешто што је стабилно и што зависи од унутрашњих фактора који су под контролом, оријентисани су на постављене задатке, и не задовољавају се лако постигнутим циљевима већ успјехом који захтјева максималне напоре, а са постизањем успеха повећавају и ниво аспирације
(Вујановић, 2015). Такође, чињеница је да многи спортисти не постигну успјех пропорционалан својим потенцијалним могућностима управо зато што немају довољно изражен мотив постигнућа (Пајевић, 2006).

Мотив постигнућа у литератури се одређује као релативно трајна диспозиција коју чини мање или више изражена потреба за компетенцијом, односно за успјешношћу у ситуацијама када је потребно достићи или превазићи неки стандард успешности (Rheinberg, 2004). Према Меклиленду (McClelland, Atkinson, Clark \& Lowell, 1953), аутору који је указао на значај мотива постигнућа, ова сложена мотивациона диспозиција садржи двије компоненте: тенденцију особе ка постављању циљева и такмичење са другим особама.

У новијим истраживањима структуре мотива постигнућа Францешко, Михић и Бала (2002а) издвојене су четири компоненте ове сложене 
мотивационе диспозиције, и то су: такмичење са другим људима, истрајност у остваривању циља, остваривање циља као извор задовољства и оријентација ка планирању. Закључак ових аутора је да су двије основне компоненте које мотив постигнућа укључује: улагање напора да се постигне оно што се сматра вриједним постављање циљева, и чиме ће се истаћи пред другима - такмичење с другима (Францешко и cap., 2002a), што одговара Маклеландовом концепту мотива постигнућа. Друге двије издвојене компоненте су инструменталне особине или облици понашања које особа развија како би била успешна у такмичењу са другим људима и/или у остваривању циљева. Наиме, особе које имају тенденцију ка такмичењу и/или постизању циља, али нису упорне, истрајне и оријентисане ка планирању, врло вјероватно неће бити успјешне (Францешко и сар., 2002а). Новија истраживања (Арсенијевић-Пухало и Пухало, 2006; Францешко, Коџопељић и Михић, 2002b; Михић, ШакотићКурбалија и Францешко, 2005) су потврдила овакву структуру мотива постигнућа. Коначно, по својој природи, мотив постигнућа спада у категорију социјалних мотива, што значи да је у великој мјери резултат процеса социјализације (McClelland et al., 1953). Резултати бројних истраживања (Beck, 2000; Францешко и сар., 20026; Лазаревић, 2011; Schunk, 2004) су показали да социјални фактори, попут културе, друштвених вриједности, породице, школе итд., утичу на степен развоја мотива постигнућа.

Петофакторски модел личности (McCrae \& Costa, 1990) претпоставља да се простор базичне структуре личности може описати дуж пет широких димензија: екстраверзија, савјесност, пријатност, отвореност ка искуству и неуротицизам. Екстраверзија се односи на степен у ком се појединацактивно ангажујеусвојојсоцијалнојсредини. Активност, друштвеност и предузимљивост су особине повезане са екстраверзијом (McCrae \& Costa, 1990). Савјесност се односи на степен у ком појединац слиједи друштвене норме и показује усмјереност на одређене циљеве. Одговорност, промишљеност и организованост су особине повезане са савјесношћу (McCrae \& Costa, 1990). Пријатност се односи на степен у ком појединац показује сарадљивост и повјерење према другима. Љубазност, кооперативност и несебичност су особине повезане са пријатношћу (McCrae \&
Costa, 1990). Отвореност ка искуству се односи на степен у ком појединац прихвата нове или неконвенционалне мисли и искуства. Маштовитост, знатижеља и далековидост су особине повезане са отвореношћу ка искуству (McCrae \& Costa, 1990). Неуротицизам се односи на емоционалну стабилност и прилагодљивост поједица. Карактеристике повезане са неуротицизмом су емоционалност, темпераментност и анксиозност (McCrae \& Costa, 1990). Петофакторски модел личности представља свеобухватну таксономију црта личности која са пет фактора обухвата нормално и патолошко јединствено поље личности (McCrae \& Costa, 1990).

У спорту се велика пажња поклања селекцији талентованих кандидата за одређену врсту спорта. Критеријуми различитих програма за "откривање талената" углавном се базирају на корелацијама између урођених способности и захтјева одређеног спорта, и на основу тога настоје предвидјети потенцијални максимални домет спортског успјеха и постигнућа (Durand-Bush \& Salmela, 2001; Lidor, Côté \& Hackfort, 2009). Међутим, спортисти се данас сусрећу са великим изазовима и искушењима у својим спортским каријерама, а у великој мјери остваривање њиховог талента и уложеног труда одређено је њиховом личношћу и мотивацијом за постизањем спортских резултата (Cox, 2005; Egloff \& Gruhn, 1996; Elumaro, 2016; Horga, 2009). Упркос томе, приликом претраживања доступне литературе нису пронађени радови који се баве релацијама димензија личности и мотива постигнућа код спортиста. Постоји тек мали број студија о релацијама димензија личности модела Великих Пет и мотива постигнућа у академском и корпоративном окружењу. Резултати ових истраживања (Busato, Prins, Elshout \& Hamaker, 2000; Dweck \& Leggett, 1988; Hart, Stasson, Mahoney \& Story, 2007; Kaiser \& Ozer, 1994; Komarraju, Karau \& Schmeck, 2009; Sharma, 2013) показују да је мотив постигнућа појединца у академском и радном контексту у значајној мјери детерминисан димензијама личности модела Великих пет. Стога је циљ овог истраживања био испитати релације димензија личности модела Великих пет и мотива постигнућа код спортиста. На основу резултата постојећих истраживања (Busato et al., 2000; Costa \& McCrae, 1988; Dveck \& Leggett, 1988; Hart et al., 2007; Kaiser \& Ozer, 1994), може се претпостави- 
ти да димензије личности модела Великих пет у значајној мјери детерминишу и мотив постигнућа код спортиста.

\section{МЕТОД}

\section{Испитаници}

У истраживању је учествовао 301 спортиста. Узорак је чинило 68,2\% мушкараца и 31,2\% жена, старости 18 до 33 године $(M=21.34, S D=2.83)$. Просјечна дужина спортског стажа је 9 година $(M$ $=9.20, S D=4.31)$. Више од половине испитаника, њих 60,8\% професионално се баве спортом, а $39,2 \%$ су рекреативци. Највише испитаника (њих $31,5 \%)$ се бави фубалом, затим, кошарком (22,7\%), каратеом (12,5\%), рукометом $(8,6 \%)$, фитнесом $(6,5 \%)$, плесом $(5,3 \%)$, одбојком $(4,9 \%)$, тенисом $(4,2 \%)$, те боди билдингом $(3,8 \%)$. Испитаници су чланови различитих спортских клубова из Републике Српске.

Истраживање је спроведено током септембра и октобра 2018. године. Подаци су прикупљани током посјете клубовима испитаника. Учествовање у истраживању је било добровољно и анонимно. Прије почетка испитивања испитаницима је наглашено да ће се подаци користити искључиво у истраживачке сврхе, а затим су им подјељени упитници чије је попуњавање трајало око 20 минута.

\section{Инструменти}

Скала мотива постигнућа (МОП2002; Францешко и сар., 20026) састоји се од 55 тврдњи распоређених у четири субскале које испитују компоненте мотива постигнућа: такмичење са другима, истрајност у остваривању циља, остваривање циља као извор задовољства и оријентација ка планирању. Задатак испитаника је да на петостепеној скали Ликертовог типа процјени у којој мјери се слаже са сваком наведеном тврдњом (од 1 - потпуно нетачно до 5 - потпуно тачно). Поузданост субскала мјерена Кромбаховим коефицијентом алфа, у нашем истраживању, износи: 90 за такмичење са другима, .77 за истрајност у остваривању циља, .86 за остваривање циља као извор задовољства, .82 за оријентацију ка планирању и 92 за комплетну скалу.

Инвентар Великих пет (The Big Five Inventory - BFI; John, Donahue \& Kentle, 1991) састоји се од 44 тврдње распоређене у пет субскала које мјере димензије личности: екстраверзија, отвореност, савјесност, пријатност и неуротицизам. Тврдње су формулисане у облику кратких фраза које се темеље на придјевима особина који су прототип модела Великих пет. Задатак испитаника је да на петостепеној скали Ликертовог типа процјени у којој мјери се слаже са сваком наведеном тврдњом (од 1 - уопште се не слажем до 5 - потпуно се слажем). Поузданост субскала мјерена Кромбаховим коефицијентом алфа, у нашем истраживању, износи износи .76 за екстраверзију, .70 за отвореност, .85 за савјесност, .69 за пријатност и .72 за неуротицизам.

Упитник о демограбским обележјима конструисан за потребе овог истраживања, састоји се од три питања о слиједећим демографским карактеристикама: пол, старост и дужина спортског стажа.

\section{Обрада података}

Уз основне показатеље дескриптивне статистике и корелациону анализу, примењена је серија хијерархијских регресионих анализа (са циљем да се искључи потенцијални утицај демографских варијабли на мотив постигнућа) да би се испитао предиктивни допринос димензија личности за мотив постигнућа и његове компоненте. Обрада података је урађена софтверским пакетом SPSS 20.0 .

\section{РЕЗУЛТАТИ}

У Табели 1 приказане су дескриптивне статистичке мјере и корелације између варијабли кориштених у истраживању. 
Табела 1 Дескриптивна статистика и корелације између испитиваних варијабли

\begin{tabular}{|c|c|c|c|c|c|c|c|c|c|}
\hline & \multirow{2}{*}{$\mathbf{M}$} & \multirow{2}{*}{ SD } & \multirow{2}{*}{ Sk } & \multirow{2}{*}{$\mathbf{K u}$} & \multicolumn{5}{|c|}{ Корелације } \\
\hline & & & & & ТСД & ИОц & ОЗЦ & ОКП & МOП \\
\hline ТСД & 68.10 & 12.92 & -.35 & -.16 & 1.00 & & & & \\
\hline иОц & 60.84 & 9.35 & .82 & .68 & $.36^{* *}$ & 1.00 & & & \\
\hline Оц3 & 56.06 & 6.344 & -.57 & -.08 & $.49^{* *}$ & $.67^{* *}$ & 1.00 & & \\
\hline ОкП & 26.79 & 6.19 & -.18 & -.42 & $.38^{* *}$ & $.54^{* *}$ & $.58^{* *}$ & 1.00 & \\
\hline МОП & 211.79 & 27.52 & -.25 & .29 & $.80^{* *}$ & $.79^{* *}$ & $.82^{* *}$ & $.73^{* *}$ & 1.00 \\
\hline E & 30.95 & 5.00 & -.62 & .73 & $.14^{*}$ & $.32^{* *}$ & $.26^{* *}$ & .08 & $.26^{* *}$ \\
\hline$\Pi$ & 31.89 & 4.80 & -.33 & .30 & -.04 & .04 & .09 & .05 & .02 \\
\hline C & 34.89 & 5.99 & -.51 & .06 & $.27^{* *}$ & $.72^{* *}$ & $.55^{* *}$ & $.53^{* *}$ & $.63^{* *}$ \\
\hline $\mathrm{H}$ & 20.54 & 4.87 & -.03 & -.42 & .03 & $-.24^{* *}$ & $-.15^{*}$ & -.08 & $-.12^{*}$ \\
\hline O & 31.25 & 5.09 & -.04 & -.29 & .10 & $.40^{* *}$ & $.36^{* *}$ & $.21^{* *}$ & $.31^{* *}$ \\
\hline
\end{tabular}

Легенда: ТСД = такмичење са другима; ИОЦ = истрајност у остваривању циља; ОЦЗ = остваривање циља као извор задовољства; ОКП = оријентација ка планирању; МОП = мотив постигнућа укупни скор; $\mathrm{E}=$ екстраверзија; $\Pi=$ пријатност; $\mathrm{C}=$ савјесност; $\mathrm{H}$ $=$ неуротицизам; $\mathrm{O}=$ отвореност$$
* p<.05 ; * * p<.01
$$

Мјере просјека и варијабилности, скјуниса и куртозиса за Скалу мотива постигнућа и Инвентар Великих пет (Табела 1), не указују на велика одступања дистрибуција од нормалне расподјеле (Tabachnick \& Fidell, 2001).

Анализа корелација између компоненти мотива постигнућа (Табела 1) показује да су све везе значајне и позитивне $(.38<r<.67)$. Разматрајући корелације између димензија личности модела Великих пет и мотива постигнућа, уочавамо да су екстраверзија, савјесност и отвореност у значајној позитивној, а неуротицизам у значајној негативној вези са мотивом постигнућа и његовим компонентама (једино компонента мотива постигнућа - такмичење са другима није у значајној вези са отвореношћу и неуротицизмом).
Мотив постигнућа и његове четири компоненте највишу корелацију остварују са савјесношћу (.27 $<r<.72)$.

У Табели 2 приказани су резултати серије хијерархијских регресионих анализа спроведених са циљем да се испита предиктивни допринос димензија личности мотиву постигнућа и његовим компонентама, изван и изнад варијансе објашњене демографским варијаблама. У свакој хијерархијској регресионој анализи, у првом кораку унијет је сет демографских варијабли: пол (бинарна варијабла кодирана као 0 = мушкарци, 1 = жене), старост и вријеме проведено у спорту, а у другом кораку димензије личности. 
Мирковић Б., Радетић Ловрић С., Релације димензија личности..., ФИЗИЧКА КУЛТУРА 2019; 73 (2): $222-229$

Табела 2 Предиктивни допринос димензија личности модела Великих пет мотиву постигнућа

\begin{tabular}{|c|c|c|c|c|c|c|c|c|c|c|}
\hline \multirow[t]{3}{*}{ Критеријум } & \multicolumn{2}{|c|}{ ТСД } & \multicolumn{2}{|c|}{ ИОЦ } & \multicolumn{2}{|c|}{ ОЗЦ } & \multicolumn{2}{|c|}{ ОКП } & \multicolumn{2}{|c|}{ МОП } \\
\hline & \multicolumn{2}{|c|}{ Модел } & \multicolumn{2}{|c|}{ Модел } & \multicolumn{2}{|c|}{ Модел } & \multicolumn{2}{|c|}{ Модел } & \multicolumn{2}{|c|}{ Модел } \\
\hline & 1 & 2 & 1 & 2 & 1 & 2 & 1 & 2 & 1 & 2 \\
\hline Предиктор & $\beta$ & $\beta$ & $\beta$ & $\beta$ & $\beta$ & $\beta$ & $\beta$ & $\beta$ & $\beta$ & $\beta$ \\
\hline Пол & $-.19^{* *}$ & $-.20^{\star \star}$ & -.07 & -.07 & -.04 & -.05 & -.08 & -.06 & $-.14^{*}$ & $-.14^{\star *}$ \\
\hline Старост & $-.16^{\star}$ & $-.18^{\star *}$ & .00 & -.06 & -.10 & $-.14^{*}$ & .03 & -.02 & -.09 & $-.14^{\star \star}$ \\
\hline Вр. у спорту & $.22^{* *}$ & $.17^{\star *}$ & .13 & .02 & $.17^{* *}$ & .09 & -.00 & -.07 & $.18^{\star *}$ & .09 \\
\hline E & & .10 & & $.10^{*}$ & & .07 & & -.07 & & $.10^{\star}$ \\
\hline$\Pi$ & & -.09 & & $-.12^{\star *}$ & & -.02 & & -.02 & & $-.09^{*}$ \\
\hline $\mathrm{C}$ & & $.29^{* *}$ & & $.67^{\star *}$ & & $.50^{\star \star}$ & & $.58^{\star \star}$ & & $.62^{* \star}$ \\
\hline $\mathbf{H}$ & & $.15^{\star}$ & & .01 & & .07 & & .09 & & $.12^{\star}$ \\
\hline $\mathbf{O}$ & & .01 & & $.15^{\star *}$ & & $.19^{\star *}$ & & .07 & & $.11^{\star}$ \\
\hline $\mathbf{R}^{2}$ & .07 & .15 & .01 & .56 & .01 & .35 & .00 & .29 & .04 & .45 \\
\hline $\mathbf{F}$ & $8.325^{\star *}$ & $7.733^{\star *}$ & 2.116 & $48.111^{\star *}$ & 2.603 & $20.764^{\star *}$ & .644 & $16.345^{\star *}$ & $4.761^{\star \star}$ & $30.963^{\star *}$ \\
\hline$\Delta \mathrm{R}^{2}$ & & .10 & & .55 & & .34 & & .29 & & .41 \\
\hline$\Delta \mathrm{F}$ & & $6.877^{\star *}$ & & $74.118^{\star *}$ & & $30.862^{\star *}$ & & $25.604^{\star \star}$ & & $44.532^{\star \star}$ \\
\hline
\end{tabular}

Легенда:ТСД = такмичење са другима; ИОЦ = истрајност у остваривању циља; ОЦЗ = остваривање циља као извор задовољства; ОКП = оријентација ка планирању; МОП = мотив постигнућа укупни скор; $\mathrm{E}=$ екстраверзија; $П=$ пријатност; $\mathrm{C}=$ савјесност; $\mathrm{H}$ = неуротицизам; $\mathrm{O}=$ отвореност; Вр. у спорту = вријеме проведено у спорту.

${ }^{\star} \mathrm{p}<.05 ;{ }^{* *} \mathrm{p}<.01 ;$

Добијени резултати (Табела 2) показују да су сви модели са укљученим предикторским сетом димензија личности статистички значајни. Такође, резултати показују да за сваку компонету мотива постигнућа, димензије личности доносе статистички значајне промјене у проценту објашњене варијансе у односу на модел чији предикторски сет укључује само демографске варијабле. Тај допринос се креће од 10\% (у случају компоненте такмичење са другима) до $55 \%$ објашњене варијансе (у случају компоненте истрајност у остваривању циља). Тренд раста у проценту објашњене варијансе након увођења сета димензија личности, указује на значајну предиктивну моћ димензија личности модела Великих пет за мотив постигнућа.

Посматрајући компоненте мотива постигнућа, уочавамо да је савјесност значајан позитивни предиктор свих компоненти мотива постигнућа.
Екстраверзија је значајан позитивни предиктор компоненте истрајности у остваривању циља ( $\beta=$ $.10, p<.05)$, а пријатност значајан негативни предиктор истрајности у остваривању циља ( $\beta=-.12$, $p<.01)$. Неуротицизам је значајан позитивни предиктор компоненте такмичења са другима ( $\beta=.15$, $p<.05)$, док отвореност ка искуству представља значајан позитивни предиктор компоненте остваривање циља као извор задовољства $(\beta=.19$, $p<.01)$ и компоненте истрајност у остваривању циља $(\beta=.15, p<.01)$.

Посматрајући укупни скор мотива постигнућа, уочавамо да су све димензије личности модела Beликих пет значајни позитивни предиктори укупног скора мотива постигнућа, осим пријатности, која је значајан негативни предиктор. Савјесност је најснажнији предиктор укупног скора мотива постигнућа $(\beta=.62, p<.01)$. 


\section{ДИСКУСИЈА}

На основу резултата постојећих студија, у којима је утврђена значајна веза између димензија личности модела Великих пет и мотива постигнућа у академском и корпоративном окружењу, циљ овог истраживања је био испитати релације димензија личности модела Великих пет и мотива постигнућа код спортиста. Добијени резултати показују да димензије личности у значајној мјери детерминишу мотив постигнућа код спортиста.

Савјесност се показала најснажнијим, позитивним предиктором укупног скора мотива постигнућа. Посматрајући компоненте мотива постигнућа, савјесност се показала значајним позитивним предиктором свих компоненти мотива постигнућа. Савјесност представља способност самоконтроле у смислу самодисциплиноване тежње ка циљевима и строгог придржавања сопствених принципа (McCrae \& Costa, 1990). Будући да је савјесност особина коју карактерише истрајност (McCrae \& Costa, 1990), може се рећи да је њена повезаност са свим компонентама мотива постигнућа очекиван резултат. Добијени резултат је у складу са резултатима претходних истраживања који показују да је савјесност у најснажнијој корелацији са мотивом постигнућа у школском и корпоративном окружењу (Busato et al., 2000; Dweck \& Leggett, 1988; Hart et al., 2007; Kaiser \& Ozer, 1994; Komarraju et al., 2009; Sharma, 2013).

Отвореност се показала значајним позитивним предиктором укупног скора мотива постигнућа и његове двије компоненте истрајност у остваривању циља и остваривање циља као извор задовољства. Ови резултати показују да отворене особе, које су посвећене проналажењу информација, и имају активан приступ у обогаћивању квалитета свог живота (McCrae \& Costa, 1990), посједују и тенденцију да буду упорне у остваривању циљева и да остварене циљеве доживљавају као награду. Такође, истраживање Харта и сарадника (Hart et al., 2007) је указало на позитивну везу отворености и мотива постигнућа у академском контексту, а истраживање Двека и Легета (Dweck \& Leggett, 1988) на позитивну везу отворености и мотива постигнућа у радном окружењу.
Пријатност се показала значајним негативним предиктором укупног скора мотива постигнућа и његове компоненте истрајност у остваривању циља. Будући да пријатност подразумјева давање већег значаја хармонији него остваривању властитих идеала и циљева (McCrae \& Costa, 1990), може се рећи да је њена негативна повезаност са истрајношћу у остваривању циља, очекиван резултат. Овај резултат је у складу и са налазима претходних истраживања који показују да је пријатност у негативној корелацији са мотивом постигнућа у академском окружењу (Hart et al., 2007).

Екстраверзија се показала значајним позитивним предиктором укупног скора мотива постигнућа и његове компоненте истрајности у остваривању циља. Екстраверзија подразумјева виталност и енергију која се може инвестирати у животне циљеве (Roberts, O’Donnell \& Robins, 2004). Такође, екстраверзија је особина коју карактерише активност, ентузијазам, енергичност и непоколебљивост (McCrae \& Costa, 1990), стога не изненађује да она код спортиста резултира и истрајношћу у оставривању циља. Такође, истраживање Комарају, Карау и Шмека (Komarraju et al., 2009) и Шарме (Sharma, 2013) су указала на позитивну везу екстраверзије и мотива постигнућа у корпоративном окружењу, а истраживање Бусата и сарадика (Busato et al., 2000) на позитивну везу екстраверзије и мотива постигнућа у академском окружењу.

Супротно резултатима претходних истраживања који указују на негативну везу неуротицизма и мотива постигнућа у академском (Hart et al., 2007) и корпоративном окружењу (Komarraju et al., 2009; Sharma, 2013), неуротицизам се показао значајним позитивним предиктором укупног скора мотива постигнућа код спортиста. Такође, неуротицизам представља значајан позитивни предиктор компоненте мотива постигнућа - такмичење са другима, што говори да, брига и стрепња у контексту спорта доприносе тенденцији појединца да се истакне пред другима и буде успешнији од других.

Коначно, иако мотив постигнућа спада у категорију социјалних мотива (McClelland et al., 1953), резултати ове студије показују да димензије личности модела Великих пет у значајној мјери детерминишу мотив постигнућа код спортиста. 


\section{ЗАКЉУЧАК}

Резултати овог истраживања су показали да димензије личности модела Великих пет у значајној мјери детерминишу мотив постигнућа код спортиста, а најснажнијом детерминатом показала се савјесност. Добијени налази су значајни како за истраживаче, ради бољег разумјевања мотива постигнућа у контексту спорта, тако и за

\section{ЛИТЕРАТУРА}

1. Арсенијевић-Пухало, А. и Пухало, С. (2006). Мотив постигнућа менаџерки и менаџера у Бањој Луци и Сарајеву. У Б. Кузмаовић и 3. Крњаић (ур.), Зборник радова Емпиријска истраживана у психологији 2006. (стр. 227234). Београд: Институт за психологију.

2. Beck, R. C. (2000). Мотивација - Теорије и начела. Јастребарско: Наклада Слап.

3. Busato, V. V., Prins, F. J., Elshout, J. J., \& Hamaker, C. (2000). Intellectual ability, learning style, personality, achievement motivation and academic success of psychology students in higher education. Personality and Individual Differences, 29(6), 1057-1068. Doi: 10.1016/S0191-8869(99)002536

4. Cox, R. H. (2005). Психологија спорта - Кониепти и примјене. Јастребарско: Наклада Слап.

5. Durand-Bush, N. \& Salmela, J. H. (2001). The development of talent in sport. In: R. N. Singer, H. A. Hausenblas, \& C. M. Janelle (Eds.), Handbook of sport psychology $2^{\text {nd }}$ ed. (pp. 269-289). New York: Wiley.

6. Dweck, C. S. \& Leggett, E. L. (1988). A SocialCognitive Approach to Motivation and Personality. Psychological Review, 95(2), 256-273. Doi: 10.1037/0033-295X.95.2.256

7. Egloff, B. \& Gruhn, A. J. (1996). Personality and endurance sport. Personality and individual differences, 21(2), 223-229. doi: 10.1016/01918869(96)00048-7.

8. Elumaro, A. I. (2016). Personality, grit and sporting achievement. Journal of sports and physical education, 3(1), 14-17. Doi: 10.9790/6737-0311417 спортске тренере и селекторе приликом селекције спортиста за такмичење. Наиме, познавање димензија личности може олакшати процјену мотива постигнућа спортисте, и на тај начи помоћи у избору кандидата за такмичење. Будући да је мотив постигнућа релевантан фактор за успјех у спорту, у даљим би истраживањима било корисно испитати и утицај осталих персоналних карактеристика на мотив постигнућа код спортиста.

9. Францешко, М., Михић, В., и Бала, Г. (2002а). Структура мотива постигнућа мерена скалом МОП2002. У Б. Чукић и М. Францешко (ур.), Личност у више културном друштву Зборник одсека за психологију Филозофског факултета у Новом Саду, 4 (стр. 134-143). Нови Сад: Филозофски факултет

10. Францешко, М., Коџопељић, Ј., и Михић, В. (20026). Неки социо-демографски и психолошки корелати мотива постигнућа. Психологија, 35 (1-2), 65-79.

11. Hart, J. W., Stasson, M. F., Mahoney, J. M., \& Story, P. (2007). The Big Five and Achievement Motivation: Exploring the Relationship between Personality and a Two Factor Model of Motivation. Individual Differences Research, 5 (4), 267-274.

12. Horga, S. (2009). Психологија спорта. Загреб: Кинезиолошки факултет.

13. John, O. P., Donahue, E. M., \& Kentle, R. L. (1991). The "Big Five" Inventory - Versions $4 a$ and 54. Berkeley: University of California, Berkeley, Institute of Personality and Social Research.

14. Kaiser, R. T. \& Ozer, D. J. (1997). Emotional stability and goal-related stress. Personality and Individual Differences, 22(3), 371-379. Doi: 10.1016/ S0191-8869(96)00208-5

15. Komarraju, M., Karau, S. J., \& Schmeck, R. R. (2009). Role of the Big Five Personality Traits in Predicting College Students' Academic Motivation and Achievement. Learning and Individual Differences, 19(1), 47- 52. Doi:10.1016/j.lindif.2008.07.001 
16. Лазаревић, Љ. (2011). Психолочке основе физичке културе. Београд: Висока спортска и здравствена школа.

17. Lidor, R., Côté, J., \& Hackfort, D. (2009). ISSP position stand: To test or not to test? The use of physical skill tests in talent detection and in early phases of sport development. International Journal of Sport and Exercise Psychology, 7(2), 131146. Doi:10.1080/1612197X.2009.9671896

18. McClelland, D. C. Atkinson, J. W., Clark, R. A., and Lowell, E. L. (1953). The Achievement motive. New York: Appleton-Century-Crofts.

19. McCrae. R. R. \& Costa, P. T. Jr. (1990). Personality' in adulthood. New York: Guilford.

20. Михић, В., Шакотић-Курбалија, Ј., и М. Францешко (2005): Мотив постигнућа. Локус контроле као мотивациони фактори европског идентитета. Психологија, 38( 4), 445-459.

21. Пајевић, Д. (2003). Психологија спорта и рекреације. Лакташи: Графомарк.
22. Rheinberg. F. (2004). Мотивација. Јастребарско: Наклада Слап.

23. Roberts, B. W., O’Donnell, M., \& Robins, R. W. (2004). Goal and personality trait development in emerging adulthood. Journal of Personality and Social Psychology, 87(4), 541-555. Doi: 10.1037/0022-3514.87.4.541

24. Schunk, D. H. (2004). Learning theories-An educational perspective. New Jersey, Pearson Prentice Hall.

25. Sharma, E. (2013). Personality Mapping: Tool to Analyze Achievement Orientation. iBusiness, 5, 59-64. Doi: 10.4236/ib.2013.52007.

26. Singer, R. N. (1972). Coaching, Athletics and Psychology. New York: McGraw Hill Book.

27. Tabachnick, B. G. \& Fidell, L. S. (2001). Using Multivariate Statistics - 4th Edition.Boston: Allyn and Bacon.

28. Вујановић, С. (2015). Мотивација и спорт. Актуелно у пракси, 25(1), 16 - 24.

Примљен: 07.02.2019.

Прихваћен: 09.03.2019.

Online објављен: 11.07.2019. 